\title{
A metaficção em Haroldo Maranhão: dicção machadiana ${ }^{1}$
}

\section{Haroldo Maranhão's metafiction: a Machadian diction}

\author{
Paulo Alberto da Silva SALES* \\ Universidade Federal de Goiás (UFG)
}

RESUMO: A metaficção não é uma prática ficcional exclusiva da contemporaneidade. Ela é uma estratégia da narrativa presente já em Dom Quixote, de Cervantes, publicado em 1605, justamente por essa narrativa criar autorreflexividade e destacar, na tessitura do romance, a mimese do processo. A recusa ao realismo formal, a autorreflexão e a presença do leitor na construção dos sentidos da narrativa foram vistas como marcas dos romances moderno e pósmoderno e, sobretudo, são perceptíveis em várias narrativas de escritores brasileiros do último quartel do século XX. O escritor paraense Haroldo Maranhão, por exemplo, possui um romance paradigmático que apresenta um teor autorreflexivo mais profundo do que de outros romancistas de seu tempo. Em seu romance Memorial do fim: a morte de Machado de Assis, Maranhão retoma aspectos biográficos, trechos fictícios e elementos intertextuais de Machado de Assis. Maranhão também retoma o próprio tom metaficcional das ficções machadianas e o problematiza em sua narrativa, publicada em 1991. Dessa forma, o romance de Maranhão 'recria' Machado de Assis na pós-modernidade brasileira.

PALAVRAS-CHAVE: Metaficção. Machado de Assis. Haroldo Maranhão.

ABSTRACT: Metafiction is not exclusive to contemporary age. It is a narrative strategy present that was already found in Dom Quixote, by Cervantes, published in 1605. In this work, we find a narrative that emphasizes autoreflexivity and highlights the process of writing the novel. A refusal of formal realism, autoreflexivity, and the reader's participation in the construction of the narrative are seen as characteristic of modern and post-modern novels. They are also found in a number of narratives written in Brazil in the last quarter of the XX century. Haroldo Maranhão, a writer from Pará, Brazil, for example, is the author of a paradigmatic novel whose autoreflexivity is more present than in other novels of his time. In his 1991 novel, Memorial do fim: a morte de Machado de Assis, Maranhão combines biographical facts, fictional passages from Machado de Assis's works and the very metafictional tone that is the hallmark of Machado's fiction. In fact, Maranhão's novel recreates Machado de Assis in Brazil's post-modern times.

KEYWORDS: Metafiction. Machado de Assis. Haroldo Maranhão.

\footnotetext{
${ }^{1}$ Este estudo é resultado de parte das pesquisas feitas em nosso doutoramento realizado nos anos de 2010 a 2014, na Universidade Federal de Goiás, sob orientação da Professora Doutora Zênia de Faria, na qual examinamos as relações dialógicas entre literatura, história e gêneros intimistas em Haroldo Maranhão.

* Doutor em Letras - Estudos Literários pela Universidade Federal de Goiás. Desenvolve pesquisa de Pós-doutorado em Letras - Teorias e Crítica da Narrativa sob supervisão da Professora Doutora Zênia de Faria.
} 


\section{Introdução}

Como já é de consenso na crítica literária, o romance brasileiro se modernizou a partir das ficções de Machado de Assis, sobretudo com as narrativas da segunda fase desse autor. Foi com a publicação, em 1881, de Memórias Póstumas de Brás Cubas, que houve uma reviravolta na forma de se narrarem eventos narrativos. Estratégias diversas foram trabalhadas na história de Brás Cubas. Dentre elas, destacamos a digressão, a intertextualidade com obras europeias e com obras da tradição (além da bíblia), a inusitada forma de contar uma história iniciando-a pelo fim e, principalmente, a dicção metaficcional, cujo assunto narrado no enredo se concentra, em vários momentos, em "como" e no "que" deve ser narrado neste mesmo enredo. O ato de explicar os meandros da ficção passa a fazer parte dos comentários do "defunto autor" no ato de recontar suas memórias. Nos outros romances machadianos da segunda fase, principalmente em Dom Casmurro (1900), Esaú e Jacó (1904) e Memorial de Aires (1907), percebe-se uma dicção metafictícia na qual a voz narrativa compartilha o fazer ficção dentro da ficção.

No Brasil, seguindo a esteira de Machado de Assis, há outros romancistas que também trabalharam com a metaficção. A título de ilustração, podemos citar Graciliano Ramos, com o romance São Bernardo, publicado em 1934; Érico Veríssimo, em $O$ resto é silêncio, de 1943; Osman Lins, em A rainha dos cárceres da Grécia, de 1976, dentre outros. Contudo, a nosso ver, foi Haroldo Maranhão, com a sua narrativa Memorial do fim: a morte de Machado de Assis, publicada em 1991, que trabalhou a metaficção em grau mais complexo, uma vez que se colocam, em um mesmo enredo, metaficção, história, biografia e intertextualidade. Para que percebamos estas questões herméticas da narrativa de Maranhão, iniciaremos nossa reflexão a partir de discussões teóricas sobre o problema da metaficção e como ela se materializa na narrativa de Maranhão.

\section{Metaficção}

O vocábulo metafiction começou a ser utilizado por volta 1970 do século XX dentro da tradição crítica norte-americana como sinônimo de ficção pós-moderna, e foi criado pelo escritor William Gass, a partir de seu livro Fiction and Figures of Life. Contudo, mesmo antes da teorização de Gass, houve uma proliferação de termos que 
surgiram desde o século XVI para tratar da ficção que volta sobre si mesma. Zênia de Faria $(2004 ; 2009 ; 2012)$ destaca o aparecimento de obras ficcionais no século XVI que apresentam a ficção do processo, como, por exemplo, o romance Le Berger extravagant, de Charles Sorel, de 1627. Discute Faria que o referido romance foi denominado como um "antirromance" porque se apresentava contrário às convenções romanescas vigentes.

A ausência de realismo presente já em romances como os de Charles Sorel, Miguel de Cervantes, Laurence Sterne, Denis Diderot e Xavier de Maistre demonstram que o problema da ficção sobre a ficção não é tipicamente contemporânea. Segundo Faria, a teoria não acompanhou a prática. Estas formas híbridas de escrituras que compartilham tanto ficção e crítica no romance apresentaram uma dissonância na recepção crítica. Para Faria (2012, p. 238), há alguns teóricos que consideram o surgimento de tais narrativas voltadas para si mesmas como marcas de modernidade. Por outro lado, uma gama de estudiosos aponta a pós-modernidade como o momento de proliferação destas obras de cuja teoria estamos nos ocupando. Ao consultarmos as críticas especializadas, constatamos que a questão fundamental é que na contemporaneidade, mais especificamente no último quartel do século XX, ainda de acordo com Faria, houve um aumento significativo na produção de narrativas brasileiras que tornaram ainda mais explícito o grau de representação da mimese do processo. E para várias realizações distintas, houve a criação de várias terminologias que tentaram explicar o problema.

O antirromance, por exemplo, foi um termo genérico aplicado às narrativas que não obedeciam ao realismo formal discutido por Watt. Laurent Lepaludier (2002) em métatextualité et métafiction, apresenta várias terminologias que são usadas pelos teóricos e críticos da contemporaneidade ao se referirem às narrativas que se voltaram sobre si mesmas. Faria (2012) acresce mais termos aos que Lepaludier já havia apontado na pesquisa antecessora. Antirromance, como já citamos antes, metaficção, narrativa pósmoderna, narrativa narcisista, ficção autorreferencial, ficção reflexiva ou autorreflexiva, ficção autoconsciente, antificção, não ficção, narrativa antimimética, ficção pós-moderna, metaficção historiográfica, fabulação, ficção neobarroca, romance de introversão, ficção introspectiva, superficção e transficção. Percebemos, também, que tais termos não são sinônimos, embora sejam empregados constantemente pela crítica.

No romance metafictício, o realismo formal é negado em função da visibilidade da mimesis do processo. Por meio de uma escrita que cria acontecimentos puros, a ficção sobre a ficção cria a autorreferencialidade. Os experimentos textuais criam a própria "realidade". 
O heterocosmo da ficção é construído, como bem discute Patricia Waugh (1984), por meio do abandono da "ilusão ficcional" do romance realista em nome da criação de uma ficção que se autoexplica. Waugh (1984, p. 6) destaca, ainda, a presença da criação imaginativa que invalida a noção de representação. A extrema autoconsciência se firma sobre a linguagem, sobre a forma literária e sobre o ato de escrever ficção. Apesar das várias possibilidades de apresentação das dimensões autorreflexivas das narrativas, o ponto em comum que as une na contemporaneidade é o fato de explorarem a teoria da ficção através da prática de escrever ficção. O prefixo meta, na linguagem, ainda segundo Waugh, referese à ordem exploratória da relação entre o sistema linguístico arbitrário e o mundo ao qual aparentemente se refere. O mundo como um livro. A autorreflexividade é uma das principais marcas da metaficcionalidade.

Ao assumir, na contemporaneidade, o espírito pós-estruturalista da repetição com diferença ao voltar sobre si mesma, a escritura autorreflexiva nos ensina, com base em Linda Hutcheon (1984), que estamos tratando de discursos. A fragmentação e a pulverização do enredo tradicional na escritura autorreflexiva não elimina e nem deve eliminar fatos históricos, por menores que sejam, marcadores da referencialidade e da realidade empírica. Não esqueçamos que a metaficção é uma ficção consciente e não um tratado teórico. E é justamente por esta razão que o leitor tem o papel fundamental de suplementar os vazios encontrados no texto: unir um fato de extração histórica, política e social às digressões e entretempos criados pela mimesis do processo. Vejamos como isso acontece na narrativa de Maranhão.

\title{
2. Metaficção machadiana em Haroldo Maranhão
}

\begin{abstract}
Tem-se que açular a memória dos leitores distraídos. Entre um e outro capítulo eles desperdiçam verbo e tempo, em palestras frívolas; bebem xerez e fumam charutos. $O$ intervalo de uma leitura dura horas, ou dias, ou sempre. Leitores assim, se pudesse, demitiria de leitor meu. Pelo santo nome de Deus, senhores avoados: Jovita era uma das criadas do Conselheiro Ayres. A que mais se afeiçoou à Leonora. Não, não. Recuso-me a lembrar-lhes quem foi Leonora. É demais.

(Haroldo Maranhão, Memorial do fim: a morte de Machado de Assis)
\end{abstract}

O teor metaficcional presente em toda a narrativa de Memorial do Fim: a morte de Machado de Assis, de Haroldo Maranhão, publicado em 1991, é a mola impulsora 
que torna o romance uma ficção-crítica com eterno retorno. Ao questionar e problematizar em todos os níveis o ato de escrever em si e as naturezas ontológicas da ficção, da biografia, da história, das cartas e dos diários, o Memorial de Maranhão é uma escritura autorreflexiva com um grau mais profundo. Herdeiro direto de Dom Quixote, Tristram Shandy, Jacques, le fataliste, Viagens à roda do meu quarto e, principalmente, de Memórias Póstumas de Brás Cubas, Esaú e Jacó, Dom Casmurro e Memorial de Aires, o romance de Maranhão é uma ficção autoconsciente que problematiza o ato de escrever em si mesmo através do desnudamento do labor ficcional.

Comecemos a analisar o romance a partir dos títulos dos micro capítulos: "O bom e o mau uso das portas"; "Capítulo da toalha"; "Embaraçosos contos"; "Entre parenthesis"; "Saltemos por cima de tudo"; "Vírgula"; "Pulo pequeno e velhusco"; "In extremis"; "Pingase ponto final"; "Não se pinga o ponto final" e "Post scriptum". Em todos esses capítulos, e em outros cujos títulos não fazem menção direta à autorreflexividade, detectamos a mimese do processo problematizada em um grau mais elevado quando comparada àqueles romances que enumeramos anteriormente e que lhe serviram de fonte inspiradora. Passemos, então, a estas averiguações.

Entre um capítulo e outro, as instâncias narrativas - que são várias - explicam questões que não se referem, apenas, às descrições do leito de morte machadiano. Aliás, a própria ideia de morte é uma "metamorte" porque ela não tem uma finalidade dentro da narrativa. Os pontos finais não são pingados. ${ }^{2}$ Maranhão prefere as vírgulas aos pontos finais, e a autorreflexão se instaura na narrativa em vários níveis, desde a forma como o eu que conduz a trama a apresenta até nas maneiras como se apropria dos fragmentos e enxertos textuais de natureza fictícia e não fictícia de Machado de Assis.

Na epígrafe deste artigo, identificamos o grau problematizador da metaficção aliado à dessedimentação dos signos machadianos. O jogo de Maranhão é uma arena autoconsciente na qual os atos descritos na narrativa se dão como lances puros e o próprio ato de lançar uma peça no jogo fictício é questionado. Tal aspecto está presente no fato de a voz narrativa chamar a atenção dos leitores distraídos - à maneira shandiana, maistreniana e machadiana - em relação aos desperdícios de concentração e à perda do foco central nos eventos narrados, enfim, em relação à interrupção da leitura por pausas frívolas. Diz-nos a

\footnotetext{
${ }^{2}$ No romance de Maranhão, o ponto final é visto com um término. Por isso, há a preferência pelas vírgulas que marcam pausas e momentos hiatos que servem, dentre outras coisas, para criar uma nova roupagem a Machado de Assis, que é recriado no heterocosmo fictício da trama.
} 
voz narrativa: "senhores avoados: Jovita era uma das criadas do Conselheiro Ayres" (MARANHÃO, 2004, p. 151). Essa Jovita é um signo muito presente na narrativa que se camufla com a feição de Leonora do Memorial de Aires. E quem fora Leonora? Quem fora Marcela? Quem fora Fidélia? Quem fora a viúva Noronha? Quem foi D. Carmo? Dona Carolina? "Marcela, foi o que entendeste? Escutaste mal. Falei Fidélia. 'Aguiar sem Carmo é nada?'. Vejamos, vejamos. Desatemos laços, se pudermos. FidéLIA lia o mar a MARcela” (MARANHÃO, 2004, p. 21).

Nessas problematizações não só dos atos da escrita em si, mas, também, das referencialidades externas ao texto literário e da própria intertextualidade que o romance estabelece com a ficção e com a biografia machadiana, a metaficção em Maranhão questiona a própria teoria romanesca como um gênero mimético. Para Linda Hutcheon (1984, p. 6), a autorreflexividade presente em ficções como o Memorial do fim tem como função maior trabalhar os engenhos internos das estruturas linguísticas e discursivas da narrativa com o crivo avaliativo e julgador dos leitores. Já em Cervantes, constatamos que, na forma romanesca metaficcional, o ato narrativo em si mesmo é, para o leitor, parte da ação. A partir do estudo pioneiro de Hutcheon e de outros teóricos como Laurent Lepaludier e Faria, é uma constante que a narrativa metaficcional conferiu poder e liberdade ao leitor na atribuição de sentidos aos acontecimentos e aos lances no jogo da escritura. Nesses romances, a linguagem constitui a realidade e, por meio disso, os leitores podem criar e conectar vários links e fios entre a biografia, a história, a literatura, a crítica e os gêneros intimistas.

Hutcheon (1984) destaca, também, que, nas narrativas narcisistas, o artista - e no caso de Maranhão, o autor empírico e mesmo o autor ficcionalizado - não aparece como um Deus criador semelhante aos prosadores e poetas românticos. O autor é, apenas, um participante inscrito em um produto social inserido no plurilinguismo romanesco como um leitor. Maranhão, antes de tudo, é um voraz leitor da ficção, da biografia e da crítica machadiana. Tal aspecto salta-nos aos olhos quando examinamos mais a fundo a narrativa Memorial do fim frente aos vários objetos aos quais ela está relacionada: à historiografia, aos gêneros intimistas e à ficção propriamente dita. Nessas junções, readaptações, mudanças e acréscimos, Maranhão faz a ficção ser, ao mesmo tempo, uma crítica da ficção. As instâncias narrativas questionam o estatuto ilusório das criações machadianas que são, a todo momento, confundidas e camufladas às figuras biográficas que cruzaram a vida de Machado. O trecho abaixo retirado do Memorial de Aires nos é necessário para ilustrarmos e estabelecermos essas conexões herméticas: 


\section{4 de fevereiro}

Eia, resumamos hoje o que ouvi ao desembargador em Petrópolis acerca do casal Aguiar. Não ponho incidentes, nem anedotas soltas, e até excluo os adjetivos que tinham mais interesse na boca dele do que lhes poderia dar a minha pena; vão só os precisos à compreensão de coisas e pessoas.

A razão que me leva a escrever isto é a que entende a situação moral dos dois, e prende um tanto com a viúva Fidélia. Quanto à vida deles, ei-la aqui em termos secos, curtos e apenas biográficos. Aguiar casou guarda-livros. D. Carmo vivia então com a mãe, que era de Nova Friburgo, e o pai, um relojoeiro suíço daquela cidade. Casamento a grado de todos. Aguiar continuou guarda-livros, e passou de uma casa a outra e mais outra, fez-se sócio da última, até ser gerente de banco, e chegaram à velhice sem filhos. É só, nada mais que isto. Viveram até hoje sem bulha nem matinada. Queriamse, sempre, se quiseram muito, apesar dos ciúmes que tinham um do outro, ou por isso mesmo. (ASSIS, 2013, p. 22-23)

No diário do Conselheiro Aires, o teor autorreflexivo está presente do início ao cabo do romance. Por meio do próprio formato em diário que foi romancizado pela ficção, o ato de escrever tornou-se, já em Machado de Assis, um ato de fazer teoria e crítica literária na ficção. Esse aspecto também é muito recorrente em Esaú e Jacó. Nesta última narrativa, nos seus cento e vinte e um capítulos, os fatos narrativos sobre a vida dos irmãos que, já no título, fazem referência à Bíblia, não chegam a representar coisa alguma. A dúvida e a oscilação, como bem apontou o crítico Hélio Guimarães (2012), são matérias recorrentes na ficção machadiana e em especial neste romance publicado em 1904, ano da morte de Dona Carolina. Em Esaú e Jacó, há a ideia de que nada se conclui e nada acontece. A voz narrativa conduz o leitor, nesse romance, aos bastidores da ficção, ao passo que levanta questões sobre os métodos que desnudam os procedimentos da escrita. Nas palavras do próprio crítico,

o romance multiplica assim as possíveis chaves interpretativas para o ódio figadal e inexplicável que une os dois irmãos gêmeos protagonistas, convocando a mitologia clássica, o Antigo Testamento, o Novo Testamento, a história das relações coloniais entre Brasil e Portugal, a história do Brasil e por aí vai... [...] Estamos diante de um romance em abismo, com vários planos de sentido correntes, o que torna difícil determinar se há e qual seria o nível alegórico principal. [...] O deslocamento crescente da responsabilidade interpretativa para o leitor é marca do romance machadiano. De Ressurreição ao Memorial de Aires, as narrativas se tornam cada vez mais exigentes conosco, leitores, que acostumamos chegar à última linha com muito mais dúvidas e perguntas do que tínhamos ao abrir o livro. Em Esaú e Jacó, a participação decisiva do leitor no processo ficcional é discutida na própria narrativa, que o representa como figura-chave do jogo ficcional. (GUIMARÃES, 2013, p. 15-16) 
Vários aspectos apontados pelo crítico na citação anterior também são aplicáveis à rapsódia ${ }^{3}$ de Maranhão. $\mathrm{O}$ problema do romance em abismo, das múltiplas possibilidades de leitura oferecidas pelos acontecimentos singulares da narrativa, além de uma série de dúvidas relativas à interpretação de diferentes passagens do romance. Neste, o leitor é convidado a dar "um", “dois" ou mais "saltos" sobre os aspectos supostamente biográficos e passa a ser um agente da construção narrativa. No capítulo VII, "Intrometediço; posto de banda pelo autor", percebemos uma mistura de traços, aspectos e fatos que seriam, a priori, das Memórias Póstumas de Brás Cubas e que são, agora, reelaborados na escritura de Maranhão:

Em lugar do capítulo LXXI, passa este a prevalecer, arredando o outro. Decisão capital assim encerra avanço sem mais volta. Ao deliberar-se alguém, inabalavelmente, por uma viagem a Friburgo, não o desconvencerá ninguém a meter-se na barca de Petrópolis.

E tanto não é projeto fraco, sujeito a guinadas, que peremptoriamente resolvo não suprimir o LXXI, que permanecerá em novo sítio pelo resto da eternidade; mas incluir este antes do LXXII, que trocará o cabeçalho pelo número LXXIII.

Precisava trazer a rol que não poucas vezes, sem que entendesse o porquê, falava a Virgília com a sensação de falar a Valéria, turbação a acreditar-se à memória, que ostenta sinais de apagamento; ou aos vês de ambos os nomes, conquanto ninguém deva alimentar dúvida de que Virgília é Virgília e Valéria é Valéria, duas nítidas criaturas que eu fundia numa só. Por quê? (MARANHÃO, 2004, p. 35)

Por meio da apropriação do trecho metafictício presente na autobiografia de Brás e por suplementá-la em forma de jogos de espelhamentos e de significantes esquizoides, Maranhão, além de problematizar a escrita de Machado que já era autorreflexiva, torna sua narrativa duplamente autoconsciente, ou melhor, metaficcional ao quadrado. E não só o teor metaficcional é revigorado, mas, principalmente, há a recuperação do riso melancólico, da ironia mórbida e da pachorra de Brás. Tudo, aqui, são pinotes: "Deixou-se escrito há linhas recuadas que se dera um belíssimo pinote. Dera-se" (MARANHÃO, 2004, p. 4). No mesmo sentido dos pinotes de Machado, em Maranhão, quem conta um conto aumenta um ponto? Sim,

\footnotetext{
3 A noção de rapsódia adotada aqui está relacionada à ideia de texto heterogêneo e permeado por diferentes formas de composição e pelas constantes digressões feitas pelas instâncias narrativas. Para tanto, baseamo-nos nos estudos de Massaud Moisés (1978), em seu Dicionário de termos literários, e em Tristram Shandy, de Laurence Sterne, para os quais a rapsódia equivale à compilação de temas e assuntos heterogêneos e de origem variada, podendo ser associado à noção de miscelânea.
} 
todavia, importa dizer que este livro é escrito com a pachorra, com a pachorra de um homem já desafrontado da brevidade do século, obra supinamente filosófica, de uma filosofia desigual, agora austera, logo brincalhona, coisa que não edifica nem destrói, não inflama nem regela, e é todavia mais do que passatempo e menos do que apostolado. Vamos lá, verifique o seu nariz, e tornemos ao emplasto. Deixemos a história com os seus caprichos de dama elegante. Nenhum de nós pelejou a batalha de Salamina, nenhum escreveu a confissão de Augsburgo; pela minha parte, se alguma vez me lembro de Cromwell, é só pela ideia de Sua Alteza, com a mesma mão que trancara o Parlamento, teria imposto aos ingleses o emplasto Brás Cubas. Não se riam dessa vitória comum da farmácia e do puritanismo. Quem não sabe que ao pé de cada bandeira grande, pública, ostensiva, há muitas vezes várias outras bandeiras modestamente particulares, que se hasteiam e flutuam à sombra daquela, e não poucas vezes lhe sobrevivem? Mal comparando, é como a arraia-miúda, que se acolhia à sombra do castelo feudal; caiu este e a arraia ficou. Verdade é que se fez graúda e castelã... Não, a comparação não presta. (ASSIS, 2008, p. 47)

Escrito com pachorra, com comparações sem relações ao assunto central da trama, com digressões e pausas para hiatos nos quais não se conclui absolutamente nada, a narrativa de Brás empresta ao romance de Maranhão a forma shandiana do horror à linha reta e do desdém a narrar fatos heroicos de maneira ordenada. E não apenas isso: as digressões facilitam a movimentação das personagens que circundam no enredo. Aí, percebemos os mecanismos de espelhamentos entre as personagens e da (não) distinção entre realidade e ficção. Personagens machadianas como D. Carmo, Fidélia, Marcela (Valongo), e as reais como Leonora (Hylda), D. Carolina, Jovita Maria de Araújo, Perpétua Penha Nolasco, dentre outras de menor importância no enredo, são peças fundamentais do "jogo de xadrez", já que, na troca de nomes e de papéis, a movimentação que cada personagem executa é estratégica dentro dos princípios que regem o tabuleiro.

A personagem Leonora, no capítulo XXXIX, “O Namenlose Freude!", 4 por exemplo, submete-se, em partes, ao jogo criado, dentro da ficção, pelo Conselheiro/Machado e regido pela voz narrativa. Ela e Machado entram em cena e representam um diálogo irreverente acerca do questionamento de seus nomes próprios que serão reescritos no heterocosmo fictício:

\footnotetext{
4 “Oh Alegria inominável!”. (Tradução nossa)
} 
Hylda é Hilda, e Hilda é Leonora. Leonora?

- Hilda, façamos um jogo.

- Um jogo, Sr. Machado?

- [...] Nunca mais, nunca mais vou chamá-la de Hilda. Concorda?

- Por que? Não entendo. Mas se Hilda é meu nome!

- Não é, não. É um jogo. Nosso. Só nosso. Você passa a ser Leonora.

- [...] Francamente... Não atinei com o espírito do seu jogo.

- Nosso jogo. Eu serei..., bem. Pensei em Florestan. Não, não. Florestan é espanhol e eu não sou espanhol. Eu serei o Aguiar ou o Ayres. Ayres também é espanhol, mas eu gosto de Ayres.

$-[\ldots]$ O Senhor!

- Vamos só olhar uma vez para trás. Uma vez. Preste atenção. A Hilda tratava o Machado de Sr. Machado. A Leonora, não. A Leonora trata o Ayres de (você é quem falou ainda agora) trata o Ayres de... meu amiguinho. A-liás, a-li-ás, você já me escreveu uma vez: a sua amiguinha... Hylda! Não esqueci. Minha memória é pouca para matérias aborrecidas. Tudo o que é agradável eu guardo na minha gaveta mágica.

- Gaveta mágica?

- Tenho. Uma gaveta mágica. É o meu segredo. Não digo a ninguém.

- [...] Você é Leonora, ex-Hilda. [...] Pensa que não reparei? Agora tem uma: Leonora é Leonora, não Leonoura, como cenoura; uma letra desequilibra, desequilibra ou não desequilibra? Leonora eu tirei da caixa mágica. (MARANHÃO, 1991, p. 130-131)

O diálogo entre Machado e Leonora apresenta um dos aspectos mais salutares do romance de Maranhão: o esmaecimento da referencialidade em prol da construção do devir com repetição crítica. Não há possibilidade de fundar uma identidade fixa no romance. Um personagem pode ser outro ao mesmo tempo e no mesmo lance, assim como acontece na narrativa de Lewis Carroll, Alice no país das maravilhas. Além disso, a mesma personagem Hilda/Hylda é designada em momentos diferentes por nomes distintos, ora como Marcela e Fidélia, embora essas duas últimas sejam readaptações ficcionais, ou melhor, ficções da ficção dentro de outra ficção.

Entretanto, há uma personagem inserida na narrativa que, diferentemente das outras citadas anteriormente, tem uma função sui generis. Anunciada no capítulo XXI, sua primeira aparição na trama dá-se no seguinte que, não menos intencionalmente, tem como título o seu nome: "Perpétua Penha Nolasco". Essa figura curiosa aparece na trama com um único propósito: obter um prefácio escrito por Machado de Assis para apresentar seu romance. Sua presença, dentro dos fios narrativos, poderia ser um indício biográfico criado pela ficção que se autorrepete. Neste capítulo, percebemos a indignação da voz narrativa diante da atitude da "nova" escritura e, por tal razão, a instância que conduz a trama expressa: 


\begin{abstract}
A romancista não se vexa de maçar a paciência alheia pedinchando prefácios! É costume que se instalou no Império, e que prospera na República. Pede-se, a uma figura em voga, endosso para letras cujo desconto o próprio emitente não fia. Já se imaginou Os lusíadas - de prefácio? Hoje, não se saberia mais quem fosse o autor do prefácio, conquanto pudesse haver enxergado até com os olhos ambos, enquanto o apadrinhado, de olho escoteiro, mais amplamente esquadrinhou os assuntos da poesia, das batalhas e de Goa. (MARANHÃO, 2004, p. 84)
\end{abstract}

A personagem Perpétua é focalizada constantemente pelos narradores que a inserem na teatralidade autorreflexiva do romance, tendo em vista que essa figura representa, mesmo ironicamente, uma espécie de personificação da angústia da influência (BLOOM, 2002) contida nos escritores atuais em relação a seus precursores. O que a romancista almeja é obter uma "transferência de personalidade" a partir do consentimento do prefácio feito por Machado. Logo, ao ostentar um nome de peso já na abertura do romance, Perpétua acredita que seu livro será sucesso absoluto. A "beletrista" vai à procura de Dr. Lúcio para que esse último entregue uma carta ao enfermo no Cosme Velho. Entretanto, não só o Conselheiro Machado findava no seu leito como Dr. Lúcio, que habitava a Tijuca, estava quase cego e com problemas de saúde. Mesmo assim, a estreante romancista consegue a carta e a submete às mãos machadianas.

A narrativa da saga de Perpétua, cujo nome faz jus a sua causa devido a suas peripécias, foram temas dos capítulos XXVIII, XXIX, XXXIV e XXXVII, intitulados "O homem é péssimo"; "Lêmures"; "Sebo!" e "Um olhar vítreo". Após os infortúnios, Paulo Jatobá, o nome adotado pela romancista, consegue, enfim, ter o tão almejado prefácio. Com ares triunfantes, Perpétua tenta de forma desajeitada, explicar o motivo que a fez tomar esse posicionamento:

- O senhor é o grande culpado, Conselheiro. Viu? Com seus romanções! Então, me atrevi a escrever o meu romancezinho, que está aqui. Será a primeira pessoa a lê-lo, ouviu? A primeira! Nem meu irmão, ouviu? Dr. Lúcio quis dar uma olhadinha, não lhe nego. Mas disse de mim para mim: o privilégio será do Conselheiro Ayres. Por sinal que ele foi muito amável com a apresentação que fez. Trouxe-lhe a mensagem; fica aqui a mesinha-decabeceira. Ele está um pouco fraquinho da vista, sabia? Coisa de nada. (MARANHÃO, 2004, p. 124-125)

No capítulo XXXVII, Machado, embora não correspondesse a nenhuma das intervenções de Paulo Jatobá, fitou-lhe um “olhar vítreo" desde o primeiro até o último 
momento em que a personagem estava em cena. E a petulância da escritora em importunar o grande escritor fluminense vai ainda mais longe:

O estilo? Ora, o estilo. O estilo é o seu, Conselheiro: o senhor ensina os novatos a escrever, ouviu? É um livrinho que captura o leitor do primeiro ao tópico final, ouviu? Poderá fazer um misteriozinho, não é mesmo? Quem será esse Paulo intrigante? E esse Jatobá de quem não se ouviu falar? Ora, temos um mestre em desatar enigmas; estou falando com ele, é ou não é? [...] Então, meu mestre e glória nacional? Vamos! Ânimo! Coragem! Querido Conselheiro: vai custar-lhe nada, um mínimo de ocupação que nestes dias de repouso consiste nisto: pensar. Estou mentindo? (MARANHÃO, 2004, p. 134)

Além de Perpétua, há também a presença fundamental da criada Jovita Maria de Araújo, que teve participação importante no desvendamento dos enigmas criados por Maranhão, ou melhor, atuou no jogo de forma decisiva a dar sentido aos fatos, como foi verificado nas discussões sobre o gênero diário. Além dessas personagens, o romance agrega, também, figuras históricas que entram no palco armado por Maranhão e que, por seu turno, rompem com o pacto realista colocando em xeque a possibilidade de conhecimento de um objeto/referência exterior ao texto (ESTEVES, 1998, p. 132).

Em virtude disso, atos vão sendo encenados à medida em que o fim que Maranhão reserva a Machado de Assis engloba os personagens/atores José Veríssimo, Mário de Alencar, Rio Branco, Euclydes da Cunha, Raimundo Correia, Astrogildo Pereira, Joaquim Nabuco, Dr. Miguel Couto, Albuquerque, Lobo Neves, Graça Aranha, Dráuzio Barreto, Dr. Lúcio de Mendonça e o próprio Machado de Assis, que responde por Conselheiro Ayres e Aguiar. Isto porque os personagens/atores citados, na verdade, em sua maioria, pessoas da vida real e contemporâneos de Machado - escritores, médicos, diplomatas - comparecem ao leito de morte de Machado para visita-lo e mesmo para perturbá-lo.

No capítulo III, intitulado "Uma carta", identificamos essas presenças desarticuladoras de personalidades reais na ficção de Maranhão. Aqui, José Veríssimo escreve a Medeiros informando-lhe a real situação de Machado:

\section{Rio, 25-09-908.}

Meu querido Medeiros.

Deixei o nosso mestre indisputado nem pior nem melhor. A doença não estagnou, e nem vejo como possa estagnar. Deus? Medeiros: Deus existe? Qual de nós acredita? O Mário? O Graça? O Lúcio? O Rodrigo? O Nabuco acredita, mas está em Washington, e além do mais Deus não fala inglês. A doença avança devagar; mas sempre avança, e quem saberá se mais devagar 
realmente? Que sabemos dos organismos vivos e esfaimados que nos roem internamente? A medicina foi além do impossível. [...] Em dados momentos, acredito que desfaleça. Será a ausência, agravando-lhe o fim?, doença sobre doença, o mal maior sobre o mal menor; e nem se saberá qual o menor e qual o maior, que um, enfim, humilha mas não mata.

(MARANHÃO, 2004, p. 19-20)

Além da inserção do historiador José Veríssimo, há também a visita desconcertante de "um certo calvo" no enredo. A personagem histórica Barão do Rio Branco, ministro de Estado permanente durante a primeira República, é uma das poucas, se não a única figura satirizada e execrada ao extremo pelo narrador, como fica perceptível a seguir:

Sob o gabinete de Ouro Preto, a calva hoje tão excelsa era antes uma calva baça que transitava não em carruagem mas nos bonds; e servia de chufas à meninada; [...]. E não se despreze a hipótese de algum moleque, atiçado por sujeito de baixa monta, ter-lhe chimpado uma chulipa com o nó dos dedos. [...] Cabeças descalvadas cativam e encorajam a faceia. (MARANHÃO, 1991, p. 140)

Nesta passagem, percebe-se uma crítica irônica na descrição da personagem histórica Barão do Rio Branco que beira a zombaria. Há, nesta retratação, uma visão paródica na qual a voz narrativa, por meio de um texto base, o retoma e o recheia de críticas e desconstruções das versões oficiais. Apesar deste procedimento ser tipicamente paródico, ele também pode ser incorporado pelo jogo textual e imagético construído pelo pastiche. Nesse pastiche que Maranhão faz de Machado de Assis, há espaço para elogios, homenagens, críticas, censuras e depreciações.

Por outro lado, a presentificação da figura de Lobo Neves, personagem da ficção machadiana, a saber, de Memórias Póstumas de Brás Cubas, manifesta-se em um sonho que o escritor/moribundo tivera. O pensamento onírico também traz novas informações que são amarradas à imensa rede palimpséstica:

$\mathrm{O}$ autor escusa-se de omitir a palestra que entretiveram Lobo Neves e o Sr. Machadinho; porque, dando como a porta do gabinete cerrada, não ousaria transpô-la por um dos fáceis arranjos que sabem empregar os autores. Foi importante o que se disseram? Não foi? Trataram da organização do gabinete João Alfredo? (MARANHÃO, 2004, p. 48)

Nesta passagem, a voz narrativa sustenta indagações e ambiguidades ao criar a expectativa de um instante de diálogo entre personagens reais e ficcionais. Mas a voz acrescenta outra informação, inesperada, que frustra o leitor. Além das menções de personalidades históricas e ficcionais, há recriações bem mais inusitadas no corpo do 
romance, principalmente quando se referem ao Conselheiro Machado. As vozes narrativas, paulatinamente, comentam a carnavalização da morte do autor carioca por intermédio de cenas com tons bem-humorados. O "vice-morto", "mortíssimo", "subvivo", é retratado de forma sarcástica e pessimista, ou na própria visão do narrador, os "moribundos fatigam-se da gente que se veste de compungida e que rouba o ar bom do aposento, para expelir um mau. Morrem, sempre mais um passo, dos murmúrios exasperantes e da expectação agourenta" (MARANHÃO, 1991, p. 107).

Assim, Memorial do fim, como algumas das narrativas pós-modernistas, tenta manter a autorreflexão associada ao contexto histórico, abrigando personalidades históricas desprovidas de versões unívocas, ao mesmo tempo que convivem com entidades ficcionais. Nesses limites quase invisíveis, essas personagens são recriadas por Maranhão e, ao mesmo tempo, convivem com personagens ficcionais, o que alimenta o caráter metaficcional do romance. Há de se destacar, também, que a diegese, ao abarcar personalidades históricas brasileiras, desestrutura os alicerces dos discursos oficiais através da perspectiva das escritas da Nova História (BURKE, 1992) no universo literário, dos mecanismos da metaficção historiográfica (HUTCHEON, 1991) e do novo romance histórico (AÍNSA, 1991). Nesse sentido, a revisão da história é feita através da retomada de um período histórico longínquo, a saber, do início do século XX, e de períodos históricos que, de alguma maneira, se ligam a ele.

Com base nos apontamentos de Aínsa (1991), que, por sua vez, baseou-se no modelo de romance histórico lukacsiano e o reconfigurou, tendo em vista as distinções apresentadas nos romances publicados nos últimos quarenta anos do século XX, criouse, então, o termo novo romance histórico. Essa tipologia se distancia do romance histórico scottiano por apresentar, dentre outras coisas, novas leituras da teoria, refutar as versões oficiais ditadas pela historiografia, além de apresentar novas especificidades, tais como a superposição de tempos que são criados em diversas modalidades expressivas, dentre elas, o pastiche.

No romance brasileiro contemporâneo, especificamente a partir da década de 1970, tal como constatado por Antonio Roberto Esteves (2007, p. 114), pode-se notar um grande incremento na publicação de narrativas, em especial, romances, que trazem fatos e personagens históricas para o centro das ações. Embora a crítica tenha dedicado 
maior atenção às literaturas hispano-americanas, essa ocorrência também pode ser constatada de forma expressiva no romance brasileiro contemporâneo.

Essa tendência de a literatura recuperar fatos históricos e os reescrever no pósmodernismo é entendida por Fredric Jameson (2007), no seu estudo “O romance histórico ainda é possível?", como o ponto culminante na diferenciação do que ele reconhece como romances históricos no modernismo e no pós-modernismo. Para Jameson (2007, p. 187), o romance histórico resultaria em tentativa sem sucesso no modernismo, porque seria muito difícil distinguir tais romances de outras obras nãohistóricas, visto que o modernismo pregava a ruptura com o passado e a criação de algo original e inconfundível que pudesse marcar a época. Eis como o pós-modernismo, na visão de Jameson (2007, p. 187), repensa essa condição. É com seu fundamental desafio à estética modernista, às formas e aos procedimentos linguísticos caracteristicamente modernistas, que o movimento pós-modernista volta a abrir um campo em que o romance histórico pode renascer, mas mediante uma abordagem nova e original do problema da referência histórica. Na impossibilidade da criação de um romance histórico no modernismo, embora o teórico norte-americano deixe em aberto as especulações, emprega-se o diagnóstico pós-modernista de que "hoje em dia a verdade histórica é abordada não pela via de verificação ou mesmo da verossimilhança, mas, sobretudo por meio do poder imaginativo do falso e do fictício, das mentiras e dos engodos fantásticos" (JAMESON, 2007, p. 201).

Memorial do fim apresenta uma nova abordagem dos fatos históricos que são amarrados aos fragmentos costurados no enredo. A reunião desses elementos também inclui, como verificado anteriormente, a presença de personalidades históricas que passam a dialogar com a ficção machadiana dentro da arena montada por Haroldo Maranhão. A presença desarticulada dessas entidades, ao abalar referências históricas e temporais na movimentação do romance, é confirmada através da afirmação do narrador no capítulo XXIV ao questionar: "Escrevi história? Não teria acertado em dizer opereta? Talvez ópera; não disse e não diria ópera bufa; cada qual dos bandos reputando-se a infusão paregórica da federação" (MARANHÃO, 1991, p. 83).

O período histórico recriado é o início do século XX, ou melhor, o ano de 1908, marcado pela morte real de Machado. Mas essa retomada não impede que outros períodos históricos sejam resgatados e bricolados ao jogo textual, tal como rege os 
princípios do pastiche. O capítulo XV, "Um evento de 1876", representa um momento distinto dos outros nos quais se apoia o enredo. O narrador convida o leitor à constatação do evento:

Convido o leitor a retomar comigo ao ano de 1876; que lhe estará senão acompanhar-me, sujeitando-se à minha onipotência, que efetua guinadas finas e volteios movidos à ação do capricho? $\mathrm{O}$ autor manda; o leitor, se for bom, sujeita-se. Tirano? Quem fez a sensata indagação? Tirano. Não estaria aqui quem lhe negasse razão. (MARANHÃO, 2004, p. 59-60)

O episódio narrado, de maneira alguma, refere-se a feitos grandiosos ou de grandes homens que o discurso histórico consagrou. A historiografia, ora, "já a perdi de vista e de lembrança" (MARANHÃO, 1991, p. 57), até porque "os referenciais históricos, mero décor, necessariamente não são históricos” (MARANHÃO, 1991, p. 185). Nessa perspectiva, o excerto, como todo o capítulo, refere-se à problematização do próprio fazer literário, ao passo que chama a atenção do leitor para o fato que será narrado, já que não deixará de ser uma mera eventualidade que poderia ter acontecido com qualquer pessoa daquela época e que não surtiu efeito algum, visto que

anos são foscos ou rutilantes, ditosos ou macambúzios, ou são um pouco de umas e outras cousas. $\mathrm{O}$ ano de 1876 deixou a memória de uma cidade bufa, ao se permitirem bengalas a fedelhos tibéricos, ensandecidos pelo junco de malinar e de dar gozos ao diabo. Mais tarde se inventariam novas modas. Já então se consentiria o uso do especial ornato às mulheres. Mulheres! De bengalas! Adeus, pobre mundo! (MARANHÃO, 2004, p. 60-61)

No capítulo XXIV, a voz narrativa faz referência ao Império e ao gabinete de Visconde de Ouro Preto, mais especificamente ao ministério de Demétrio Ribeiro. A discussão central baseia-se nos resquícios monárquicos que ainda resistem à ascensão da República porque "são trabalhos, os mesmos, que se deram no Império e se dão na República" (MARANHÃO, 1991, p. 83). Percebe-se no referido capítulo a intenção da recriação de um momento da história brasileira através de "assuntos nublosos" que avaliam criticamente, com a visão problematizadora do narrador, os fatos ocorridos:

O Sr. Custódio! Esse homem de Itapira bateu palmas à porta do governo pelas mãos dos procuradores Jules Géraud \& Leclerc, agentes de privilégios. Sorriu-se quieto na cama, enquanto alguém chegava mal pisando o soalho, para não agastar quem apenas mantinha os olhos fechados. De olhos assim, e face calma, o moribundo, sem dores e sem mais incômodos, em dilatados passeios por países das lembranças. Sim, sim, Jules Géraud \& Leclerc. Exatamente. Exatamente Custódio, tendo ficado o couce do nome no ano de 92. Nesse 92 o itapirense suplicou ao Presidente Floriano benefícios e vantagens para uma supina e supimpa invenção, que foi causando risos por onde circulavam os papeis: um cognac cristalizado! (MARANHÃO, 1991, p. 84) 
A fina condenação do momento histórico é feita não pelo resgate das versões originais, mas pelo viés da fantasia e da possibilidade de recriar o passado e reavaliá-lo, é uma particularidade dos romances pós-modernistas brasileiros e que também se faz presente em Memorial do fim. Em contrapartida, diferentemente dos outros romances que se apoiam na historiografia e a reescrevem "de baixo pra cima", 5 assim como ocorre nos romances Viva o povo brasileiro, de João Ubaldo Ribeiro, Galvez, o imperador do Acre, de Márcio Souza, Cães da província, de Luiz Antonio de Assis Brasil, e A casca da serpente, de J. J. Veiga, no romance de Maranhão há mais vestígios de reorganização de extratos textuais que primam em criar suas próprias referências, tendo como pano de fundo, alguns aspectos da História protagonizada por alguns membros da elite nacional. O que difere esse romance dos outros e o que o torna, de certa forma, mais hermético é sua capacidade de não só resgatar e problematizar períodos e fatos passados, mas também, inserir no corpo do texto reorganizações de textos e de personagens de diferentes momentos de nossa história política e literária.

\section{Considerações finais}

A metáfora do caleidoscópio que, no texto de Maranhão, é constituída pela sua constante movimentação de eixos e partes desconexas que são reajustadas pelo jogo textual do pastiche, representa o não-lugar e o descaminho articulado pelo romance. Por ser uma construção em pastiche, a obra possibilita essa reviravolta temporal que não demarca territórios firmes e a torna, em certa medida, aérea e espacial. O que Maranhão fez foi entrelaçar diferentes épocas e elementos, a fim de desconstruir uma massa heteróclita e opaca. Para que se visualize melhor esses procedimentos, voltemo-nos à capa do romance publicado pela editora Planeta em 2004. Nela, constatamos uma paisagem turva, mas que o leitor consegue identificar, como pano de fundo, o Rio de Janeiro machadiano. Já na capa da primeira edição, que estamos a utilizar nas citações, há a marca específica machadiana: o olhar e os óculos. Partindo dessas questões, entendemos que o acréscimo da palavra fim no romance de Maranhão, não pode ser entendido como uma consequência última e que não há mais possibilidades de se ler

\footnotetext{
${ }^{5}$ Ao utilizarmos essa noção, estamos nos referindo aos estudos de Jim Sharpe, sobretudo aos estudos da nova história, cujos discursos dos silenciados pela historiografia são revistos e são considerados como arquivos importantes para a nova historiografia.
} 
Machado de Assis. Lê-se o outro na aporia. A autorreferencialidade, nesse romance, recria a criação pelo não dito. Sua linguagem cria novas "realidades" que não têm compromisso com a verossimilhança aristotélica, mas sim, com a envergadura textual e com sua própria realidade discursiva:

\begin{abstract}
Como se vai ver, não se pingam ii; muito menos ponto final. $\mathrm{O}$ procedimento, de se porem pontos, e finais, induz terminação peremptória de alguma cousa certa. Ponto. Final. Não se graceja com pontos finais; nunca se soube disso. O assunto de que se cuida está de pé, animosíssimo, airoso se mexe, sorri. Por ora, apalpo uma necessidade intimativa do corpo restringida ao nariz. Narizes movem-se a rapé como as carroças a bois, e meu rapé não sei onde o pus. Desço a uma tabacaria. Narizes clamam cuidados mais extensos e intensos que romances. Romances interrompem-se. Sei de autor que escreveu dous capítulos e deixou o resto para depois. O depois não houve, porque, enquanto andava o depois, o romancista bateu o pacau. O rapé não sabe fazer-se esperar. Até hoje, não apurei qual o mais importante à vida, se o ar, ou se o rapé. (MARANHÃO, 2004, p. 183)
\end{abstract}

Por sua forma autoconsciente e autorrepetida, o romance de Maranhão recria o dito pelo não dito, seja nas construções dos novos lances feitos nos jogos de palavras, seja no revisionismo histórico feito pela metaficção historiográfica ou mesmo pelo teor irônico e crítico da desconstrução da noção de biografia tradicional. Por isso, repetir é inovar. Ser original a partir da diferença e repetição é rememorar e refazer o outro de outra forma, semelhante na forma mas com singularidades na essência. E revisitar o bruxo do cosmo velho, com novas roupagens e mélanges entre a ficção/história/biografia, significa fazer reviver o maior escritor brasileiro em nossa contemporaneidade.

\title{
REFERÊNCIAS
}

AÍNSA, F. La nueva novela histórica latinoamericana. Plural, México, n. 240, p. 82-85, 1999.

ASSIS, M. Memorial de Aires. Rio de Janeiro: Nova Fronteira, 2013.

BLOOM, H. A angústia da influência. Rio de Janeiro: Imago, 2012.

CERVANTES, M. O engenhoso fidalgo D. Quixote de La Mancha. Primeiro e segundo livro. Tradução de Sérgio Molina. São Paulo: Ed. 34, 2002.

ESTEVES, A. R. O novo romance histórico brasileiro. In: ANTUNES, L. (Org.).

Estudos de literatura e linguística. São Paulo: Editora Arte e Ciência/Faculdade de

Ciências e Letras de Assis - UNESP, 1998. p. 123-158. 
O romance histórico brasileiro contemporâneo. São Paulo: Editora Unesp, 2010.

FARIA, Z. A metaficção revisitada: uma introdução. Signótica, Goiânia, v. 24, n. 1, p. 237-251, jan./jun. 2012.

Nas fronteiras da ficção: a metaficção em André Gide. In: SANTOS, P. S. N.

(Org.). Divergências e convergências em literatura comparada. Campo Grande: UFMS, 2004. p. 69-84.

A rainha dos cárceres da Grécia: metaficção e mise en abyme. In: FARIA, Z.;

FERREIRA, H. (Orgs.). Osman Lins: 85 anos. A harmonia de imponderáveis. Recife:

Editora Universitária da UFPE, 2009. p. 257-274.

GUIMARÃES, H. Um romance em abismo. In: ASSIS, M. Esaú e Jacó. São Paulo:

Companhia das Letras, 2012. p. 9-20.

HUTCHEON, L. Narcissistic Narrative: the Metafictional Paradox. New York:

Methuen, 1984.

Poética do pós-modernismo: história, teoria e ficção. Tradução de Ricardo

Cruz. Rio de Janeiro: Imago, 1991.

JAMESON, F. O romance histórico ainda é possível? Novos Estudos/ CEBRAP, São

Paulo, n. 77, p. 185-203, 2007.

LEPALUDIER, L. Métatextualité et métafiction: théorie et analyses. Rennes: Presses

Universitaires de Rennes, 2002. p. 9-13.

MARANHÃO, H. Memorial do fim: a morte de Machado de Assis. São Paulo: Marco Zero, 1991.

Memorial do fim: a morte de Machado de Assis. São Paulo: Planeta, 2004.

PAES, J. Sterne ou o horror à linha reta. In: STERNE, L. A vida e opiniões do cavaleiro Tristram Shandy. Tradução de José Paulo Paes. São Paulo: Companhia das Letras, 1998. p. 7-38. 